\title{
Effect of Biofertilizers and Vermicompost on Pomegranate (Punica granatum L.) Cutting
}

\author{
Jayashri Rathore*, G.L. Sharma and Tapas Chaudhury \\ Department of Fruit Science, IGKV Raipur - 492012 (C.G.), India \\ *Corresponding author
}

K e y w o r d s
Pomegranate, PSB,
Azotobactor,
Azospirillum,
Vermicompost,
Punica granatum

\section{A B S T R A C T}

The present experiment entitled Effects of biofertilizers and vermicompost on rooting of pomegranate (Punica granatum L.) cuttings was conducted at nursery, Horticulture Farm, Indira Gandhi Krishi Vishwavidyalaya, Raipur (C.G.), during the period of 2018-19.The present experiment was conducted to study the effect of diffetent biofertilizers, vermicompost and water as control (viz, control, PSB, Azotobactor, Azospirillum, Vermicompost @ 5\% of rooting media) with three replication in a complete randomized design (CRD), under shade net condition. The study revealed that significant differences were existed among the treatments for different rooting and shooting parameters. Among the different treatments the earliest sprouting of cutting as well as significantly highest percentage of success, number of leaves per shoot, length of root, diameter of root, fresh weight of roots, and number of roots per cutting were observed in PSB @ 5\% rooting media followed by Azotobactor @ 5\% rooting media. However the performance of cutting in treatment control was inferior.

\section{Introduction}

Pomegranate (Punica granatum L.) belonging to family Lythraceae, is an ancient fruit originated in Persia, Afghanistan and Baluchistan (De Candolle, 1967). Pomegranate is important crop of India and is said to be native to Iran (Persia) have some special botanical characteristics, the tree have a identical bushy shape having multiplestems, the bushiness in plant is because of suckers routinely arising from the base. The plant has an average height of 5-8 $\mathrm{m}$ tall. The plant is normally deciduous in nature. The newly arrived shoots are thin and weepy caring thorns. The color of the leaves is dark green with a shiny appearance and the size of the leaves is small with alternate arrangement. The plant is monoecious with two types of conspicuous flowers which arise in the new grown stems in the spring season, major bloom period is the spring season. The 
nutritive value of pomegranate fruits is very high and has several health benefits. Pomegranate fruits are rich in vitamin $\mathrm{C}$, potassium and antioxidants. Nutritional value of $100 \mathrm{~g}$ of edible arils is having $346 \mathrm{KJ}$ energy, $18.7 \mathrm{~g}$ carbohydrates, $13.7 \mathrm{~g}$ sugars, $1.7 \mathrm{~g}$ protein, $1.2 \mathrm{~g}$ fat, $236 \mathrm{mg}$ potassium, 10 $\mathrm{mg}$ vitamin $\mathrm{C}, 0.07 \mathrm{mg}$ thiamine and $4.0 \mathrm{~g}$ dietary fibre. The fruits also have therapeutic values accompanying considerable pharmacological properties like antimicrobial, antiviral and antimutagenic effects (Negi et al., 2003; Seeram et al., 2005).

Pomegranate is propagated by both sexual and asexual means. Rhizogenesis is the most habitually used organogenetic phenomenon in vegetative multiplication of pomegranate. Pomegranates can be propagated using both softwood or hardwood cuttings, but hardwood cuttings are commercially adopted methods. some biofertilizers play important role in rooting of cuttings, by making the nutrients available to the growing roots.PSB is responsible for increasing the availability of phosphorus to the root zones of the plants. Azotobactor and Azospirillum helps to increase the uptake of nitrogen and other nutrients by making them available by the plants. nowadays organic pomegranates production requires the cutting which are propagated by utilization of organic natural products, which can be done by using biofertilizers and organic compost.

\section{Materials and Methods}

The present investigation was carried out from September 2018 to February 2019 at nursery Horticulture Farm, College of Agriculture, Indira Gandhi Krishi Vishwavidyalaya, Raipur (C.G.). The type of cuttings used was hard wood cuttings of uniform size $(15-20 \mathrm{~cm}$ long) with 5-6 functional buds were taken from vigorous, healthy plants of pomegranate variety Super
Bhagva. For the preparation of cutting healthy, vigorous, disease free plant of pomegranate variety Super bhagwa was selected. The partially matured branches, $0.75-1.00 \mathrm{~cm}$ in thickness were taken for cuttings preparation. The cuttings of $15-20 \mathrm{~cm}$ in length with 5-6 functional buds were prepared for planting and the leaves removed entirely. Shortly after their preparation, cuttings were kept in water to maintain the amount of moisture until planting time. Whereas, bio fertilizers and vermicompost @ $5 \%$ were mixed as per treatment in the rooting medium. Two third parts of the treated cuttings were placed in the rooting media at a slight angle (about $60^{\circ}$ ) vertical to the plane. The rooting media was provided water to supply moisture to the cutting and soil around the cutting area was pressed lightly to fix the cutting in rooting media.

\section{Results and Discussion}

\section{Days taken to start sprouting of cuttings}

Data presented in table 1 shows that there was a significance difference present between the treatments, for the days taken to start sprouting and the days taken for the initiation of sprouting of cuttings ranged from 8.67 days to 12.00 days. The earliest sprouting of cutting was recorded in PSB @ 5\% of rooting media (8.67 days), followed by Vermicompost @ 5\% of rooting media (9.33days). Whereas, late sprouting of cuttings (12.00 days) were recorded under control. The result is in accordance with Wahab et al., 1999

\section{Days taken to $50 \%$ sprouting of cuttings}

The Data presented in table 1 shows that the days taken to $50 \%$ sprouting of cutting ranged from 27.33 to 30.67 days. The minimum days taken to $50 \%$ sprouting of cuttings was observed under PSB @ 5\% of rooting media 
was (27.33 days), followed by Azotobactor@ $5 \%$ of rooting media (27.67 days).Whereas, maximum days taken to $50 \%$ sprouting of cuttings (30.67 days) were recorded under control. PSB causes a significant increase in earliness of sprouting and $50 \%$ sprouting of cuttings, (Yadav et al., 2002) in phalsa. It might be due to increase in the level of endogenous auxin by applying PSB.

\section{Percentage of success of cuttings}

The data presented in table 1 shows that the percentage of success of cuttings ranged from 66.67 to $76.67 \%$. The maximum percentage of success of cutting was observed under PSB @ $5 \%$ of rooting media was (76.67\%).Whereas, minimum percentage $(66.67 \%)$ of success of cuttings was recorded under control. The result is in hormony with Slankis et al., 1973

\section{Number of shoots per cutting}

The data presented in the table 2 at 30 DAP shows that the number of shoots per cutting ranged from 3.27 to 4.07 . The maximum number of shoots per cutting was observed under Azotobactor @ 5\% of rooting media (4.07).Whereas, minimum number of shoots per cutting were observed under Control (3.27). At 60 DAP the number of shoots per cutting ranged from 4.20 to 5.07. The maximum number of shoots per cutting was observed under Azospirillum @ 5\% of rooting media (5.07). Whereas, minimum number of shoots per cutting were observed under Control (4.20). At 90 DAP the number of shoots per cutting ranged from 4.67 to 6.20 . The maximum number of shoots per cutting was observed under PSB @ 5\% of rooting media (6.20). Whereas, minimum number of shoots per cutting were observed under Control (4.67). At 120 DAP the number of shoots per cutting ranged from 5.47 to 7.07. The maximum number of shoots per cutting was observed under PSB @ 5\% of rooting media (7.07). Whereas, minimum number of shoots per cutting were observed under Control (5.47). At 150DAP the number of shoots per cutting ranged from 6.00 to 7.67 . The maximum number of shoots per cutting was observed under PSB @ 5\% of rooting media (7.67). Whereas, minimum number of shoots per cutting were observed under Control (6.00). At 180DAP the number of shoots per cutting ranged from 6.80 to 8.27. The maximum number of shoots per cutting was observed under Azotobactor @ 5\% of rooting media (8.27).Whereas, minimum number of shoots per cutting were observed under Control (6.80).

\section{Length of shoots $(\mathrm{cm})$}

Data presented in the table 3 shows that, at 30 DAP the length of the longest shoots per cutting ranged from 8.41 to 11.44 . The maximum length of shoots per cutting was observed under PSB @ 5\% of rooting media (12.07). Whereas, minimum length of shoots per cutting were observed under Control (8.40). At 60 DAP the length of the longest shoots per cutting ranged from 15.09 to 19.01 . The maximum length of shoots per cutting was observed under $P S B$ @ 5\% of rooting media (19.01). Whereas, minimum length of shoots per cutting were observed under Control (15.09). At 90 DAP the length of the longest shoots per cutting ranged from 20.47 to 21.89. The maximum length of shoots per cutting was observed under PSB @ 5\% of rooting media (21.89). Whereas, minimum length of shoots per cutting were observed under Control (20.47). At 120 DAP the length of the longest shoots per cutting ranged from 23.25 to 26.44. The maximum length of shoots per cutting was observed under PSB @ $5 \%$ of rooting media (23.25). Whereas, minimum length of shoots per cutting were observed under Control (26.44). At 150 DAP the length of the longest shoots per cutting 
ranged from 25.81 to 29.72 . The maximum length of shoots per cutting was observed under PSB @ 5\% of rooting media (29.72). Whereas, minimum length of shoots per cutting were observed under Control (25.81). At 180 DAP the length of the longest shoots per cutting ranged from 27.79 to 31.41 . The maximum length of shoots per cutting was observed under PSB @ 5\% of rooting media (31.44). Whereas, minimum length of shoots per cutting were observed under Control (27.79).

\section{Number of leaves per shoot}

Data in table 4 shows that, at 30 DAP the number of leaves per shoots ranged from 8.73 to 10.60 . The maximum number of shoots per cutting was observed under PSB @ 5\% of rooting media (10.60).Whereas, minimum number of leaves per shoots were observed under Control (8.40). At 60 DAP the number of leaves per shoots ranged from 14.33 to 17.60. The maximum number of shoots per cutting was observed under PSB @ 5\% of rooting media (17.60).Whereas, minimum number of leaves per shoots were observed under Control (14.33). At 90 DAP the number of leaves per shoots ranged from 20.27 to 23.60. The maximum number of shoots per cutting was observed under PSB @ 5\% of rooting media (23.60). Whereas, minimum number of leaves per shoots were observed under Control (20.27). At 120 DAP the number of leaves per shoots ranged from 24.93 to 27.13 . The maximum number of shoots per cutting was observed under PSB @ $5 \%$ of rooting media (27.13). Whereas, minimum number of leaves per shoots were observed under Control (14.93). at 150 DAP the number of leaves per shoots ranged from 27.40 to 30.13 . The maximum number of shoots per cutting was observed under PSB @ $5 \%$ of rooting media (30.13). Whereas, minimum number of leaves per shoots were observed under Control (27.40). At 180 DAP the number of leaves per shoots ranged from 29.87 to 32.73 . The maximum number of shoots per cutting was observed under PSB @ $5 \%$ of rooting media (32.73). Whereas, minimum number of leaves per shoots were observed under Control (29.87). The result is in accordance with Hakim et al., 2018.

\section{Total number of leaves per cutting}

The data in table 5 shows that, at 30DAP the total number of leaves per cutting ranged from 31.40 to 38.00 . The maximum number of leaves per cutting was observed under PSB@ 5\% of rooting media (38.00). Whereas, minimum number of leaves per cutting were observed under Control (31.40). At 60DAP the total number of leaves per cutting ranged from 65.33 to 73.93 . The maximum number of leaves per cutting was observed under PSB@ 5\% of rooting media (73.93). Whereas, minimum number of leaves per cutting were observed under Control (65.33). At 90, 120, 150 and 180 DAP the total number of leaves per cuttings ranged from 75.33 to $86.33,83.60$ to $90.40,86.67$ to 95.27 and 89.40 to 97.07 respectively. The maximum number of leaves per cutting was observed PSB @ 5\% of rooting media (86.33, 90.40, 95.27 and97.07).Whereas, minimum number of leaves per cutting were observed under Control (75.33, 83.60, 86.6 and 89.40) respectively.

\section{Survival percentage of cuttings}

The data presented in table 6 shows that the survival percentage of cuttings ranged from 56.67 to $70.00 \%$. The maximum survival percentage of cutting was observed under Azotobactor and Azospirillum @ 5\% of rooting media $(70.00 \%)$. Whereas, minimum percentage $(56.67 \%)$ of success of cuttings was recorded under control. The result is in same line with Sonawane and Konde (1997) 
Table.1 Effect of biofertilizers on days taken to start sprouting, days taken to $50 \%$ sprouting, success percent

\begin{tabular}{|l|l|l|l|}
\hline Treatment & $\begin{array}{l}\text { days taken to start } \\
\text { sproting }\end{array}$ & $\mathbf{5 0 \%}$ sprouting & $\begin{array}{l}\text { success } \\
\text { cutting }\end{array}$ \\
\hline Control & 12.00 & 30.67 & 66.67 \\
\hline PSB & 8.67 & 27.33 & 76.67 \\
\hline Azotobactor & 9.67 & 27.67 & 73.33 \\
\hline Azospirillum & 9.67 & 28.00 & 73.33 \\
\hline Vermicompost & 9.33 & 28.00 & 73.33 \\
\hline
\end{tabular}

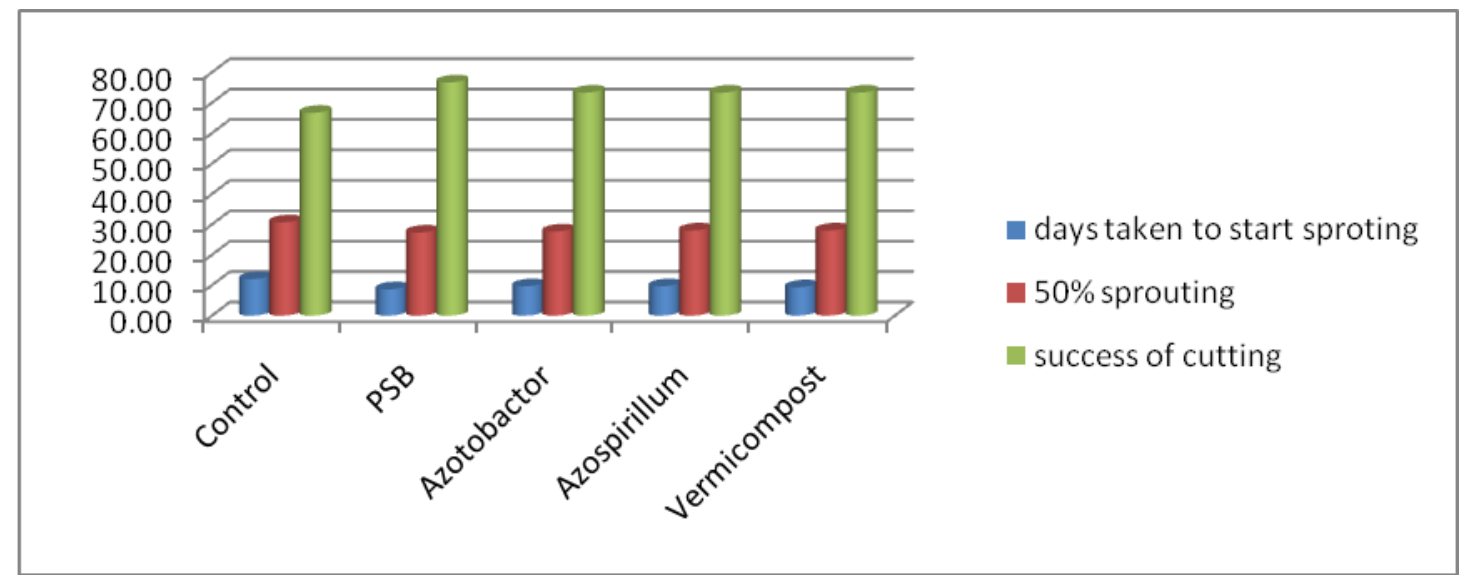

Table.2 Effect of bio control agents on number of shoots per cutting

\begin{tabular}{|l|l|l|l|l|l|l|}
\hline Treatment & 30 DAP & 60DAP & 90DAP & 120DAP & 150DAP & 180DAP \\
\hline Control & 3.27 & 4.20 & 4.67 & 5.47 & 6.00 & 6.80 \\
\hline PSB & 3.87 & 5.00 & 6.20 & 7.07 & 7.67 & 7.67 \\
\hline Azotobactor & 4.07 & 5.00 & 5.87 & 7.00 & 7.33 & 8.27 \\
\hline Azospirillum & 3.60 & 5.07 & 5.87 & 6.73 & 7.33 & 8.07 \\
\hline Vermicompost & 3.87 & 4.87 & 5.67 & 6.63 & 7.20 & 7.93 \\
\hline
\end{tabular}

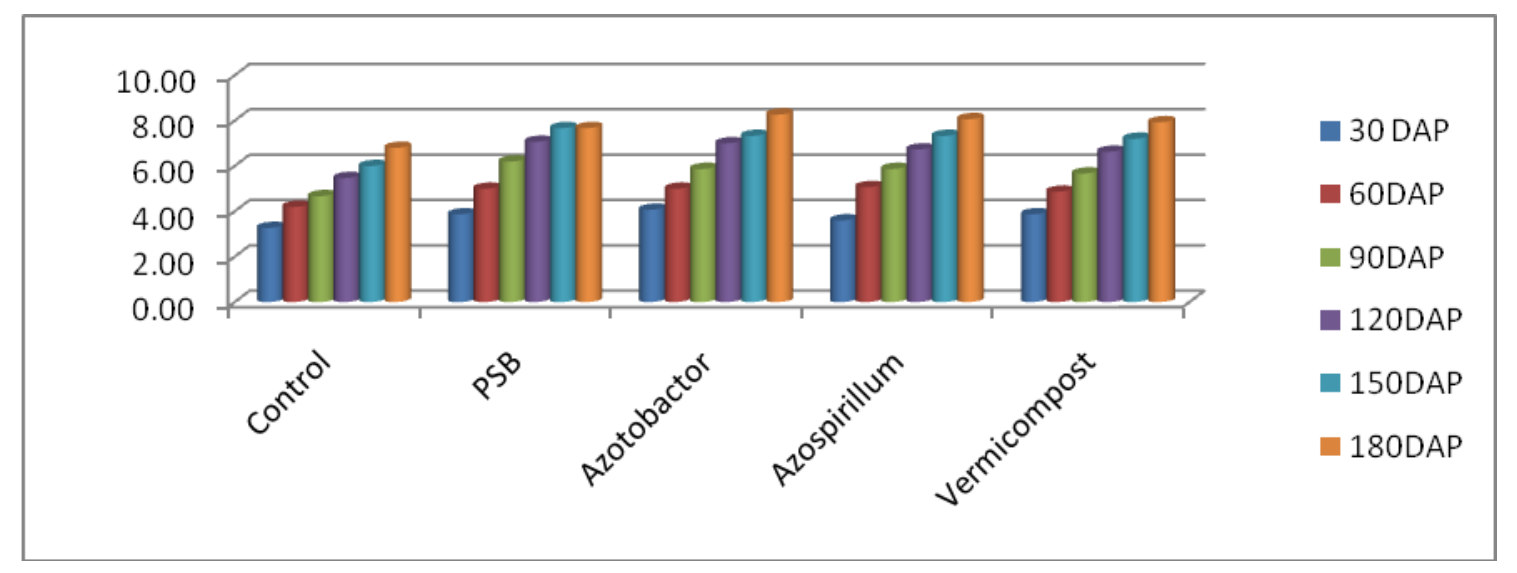


Table.3 Effect of bio control agent on length of shoots

\begin{tabular}{|l|l|l|l|l|l|l|}
\hline Treatment & 30 DAP & 60DAP & 90DAP & 120DAP & 150DAP & 180DAP \\
\hline Control & 8.41 & 15.09 & 20.47 & 23.25 & 25.81 & 27.79 \\
\hline PSB & 11.44 & 19.01 & 21.89 & 26.44 & 29.72 & 31.41 \\
\hline Azotobactor & 10.61 & 17.68 & 20.93 & 26.43 & 29.21 & 30.43 \\
\hline Azospirillum & 10.39 & 17.22 & 21.51 & 25.34 & 29.26 & 30.57 \\
\hline Vermicompost & 10.97 & 17.96 & 20.90 & 26.15 & 29.07 & 30.28 \\
\hline
\end{tabular}

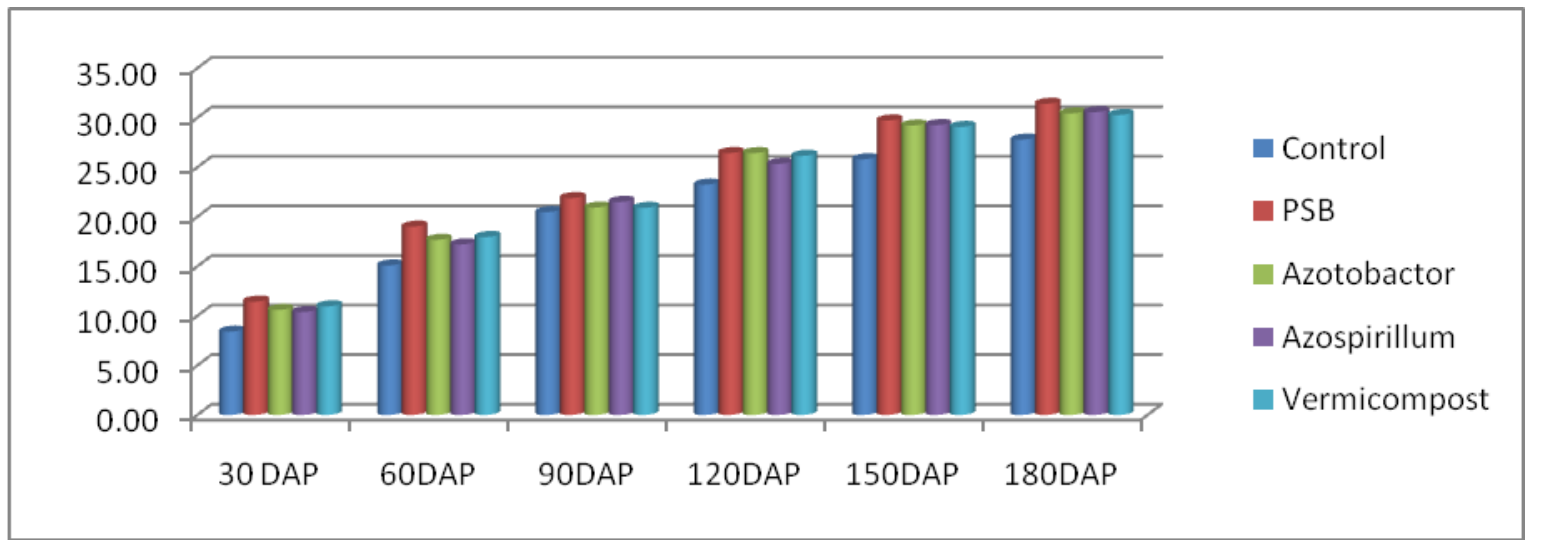

Table.4 Effect of bio control agent on number of leaves per shoots

\begin{tabular}{|l|l|l|l|l|l|l|}
\hline Treatment & $\begin{array}{l}\text { 30 } \\
\text { DAP }\end{array}$ & 60DAP & 90DAP & 120DAP & 150DAP & 180DAP \\
\hline Control & 8.73 & 14.33 & 20.27 & 24.93 & 27.40 & 29.87 \\
\hline PSB & 10.60 & 17.60 & 23.60 & 27.13 & 30.13 & 32.73 \\
\hline Azotobactor & 10.27 & 17.13 & 22.47 & 26.67 & 29.80 & 32.07 \\
\hline Azospirillum & 10.33 & 16.93 & 23.07 & 26.80 & 29.67 & 31.93 \\
\hline Vermicompost & 10.47 & 17.20 & 22.87 & 26.87 & 29.67 & 31.93 \\
\hline
\end{tabular}

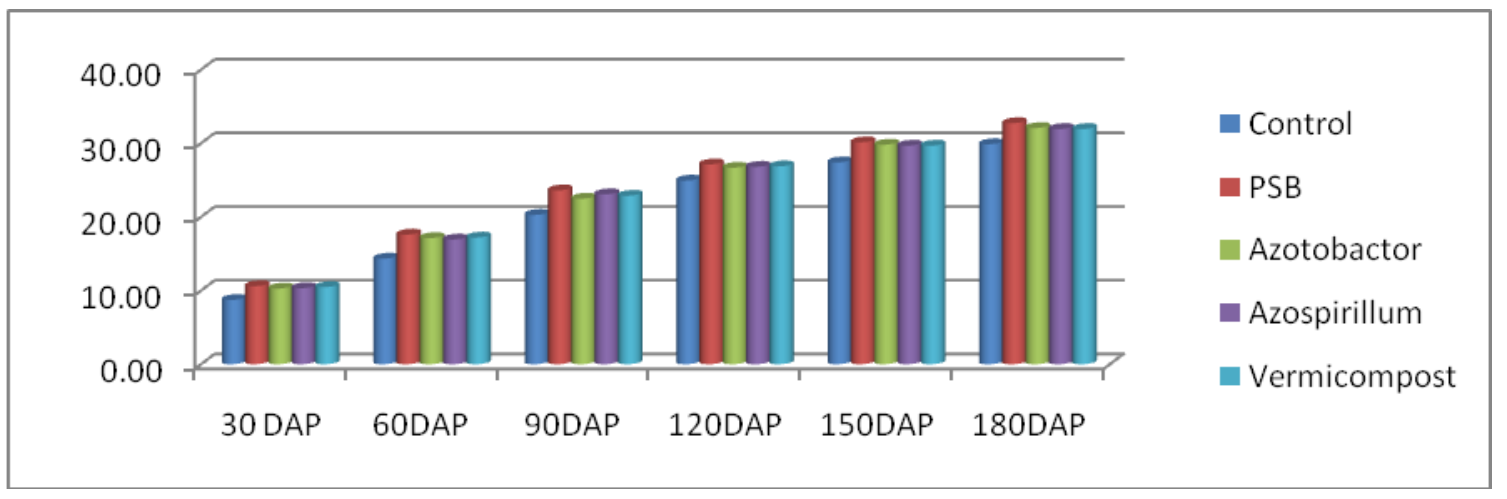


Table.5 Effect of bio control agent on total number of leaves per cutting

\begin{tabular}{|l|l|l|l|l|l|l|}
\hline Treatment & $\begin{array}{l}\text { 30 } \\
\text { DAP }\end{array}$ & 60DAP & 90DAP & 120DAP & 150DAP & 180DAP \\
\hline Control & 31.40 & 65.33 & 75.33 & 83.60 & 86.67 & 89.40 \\
\hline PSB & 38.00 & 73.93 & 86.33 & 90.40 & 95.27 & 97.07 \\
\hline Azotobactor & 37.00 & 71.93 & 82.53 & 88.60 & 93.33 & 95.93 \\
\hline Azospirillum & 36.47 & 70.93 & 81.67 & 88.27 & 93.33 & 95.87 \\
\hline Vermicompost & 37.00 & 72.53 & 82.60 & 89.27 & 93.33 & 96.20 \\
\hline
\end{tabular}

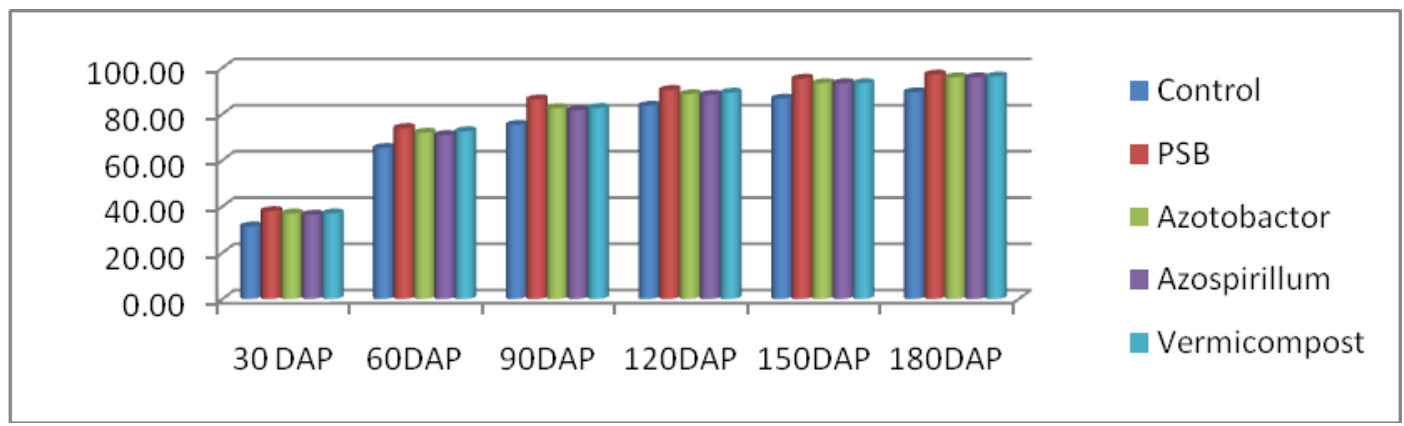

Table.6 Effect of bio control agent on survival percentage, Number of roots, Length of roots

\begin{tabular}{|l|l|l|l|}
\hline Treatment & Survival \% & $\begin{array}{l}\text { no } \\
\text { roots/cuttings }\end{array}$ & of \\
\hline Control & 56.67 & 25.27 & 20.96 \\
\hline PSB & 66.67 & 31.67 & 26.39 \\
\hline Azotobactor & 70.00 & 30.60 & 25.67 \\
\hline Azospirillum & 70.00 & 30.67 & 25.44 \\
\hline Vermicompost & 66.67 & 31.53 & 26.19 \\
\hline
\end{tabular}

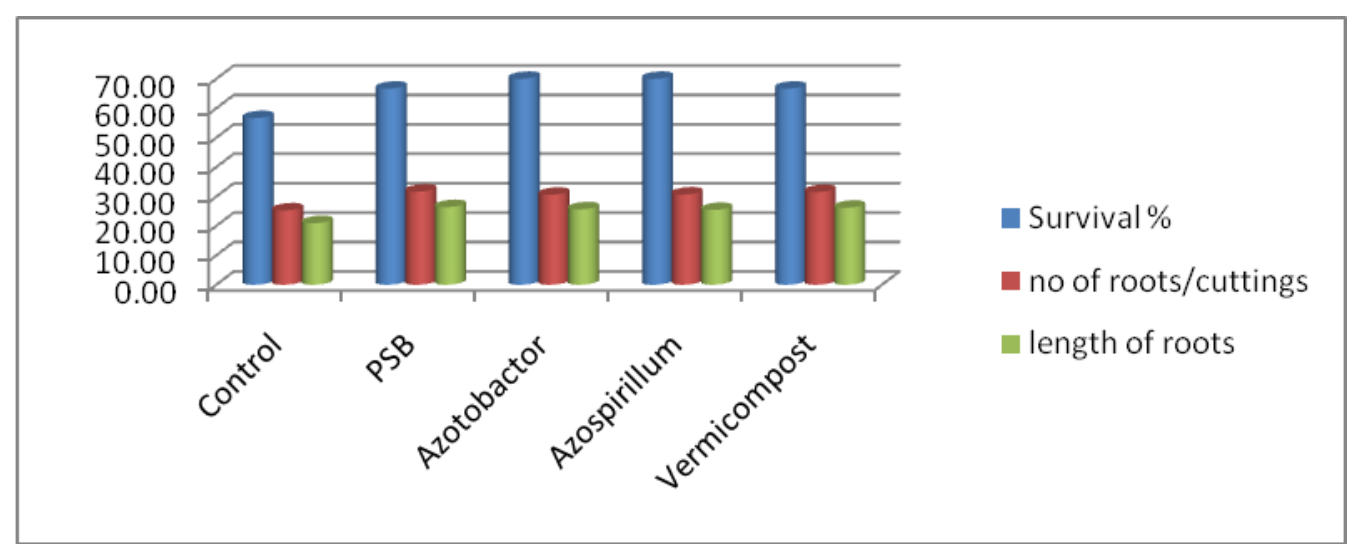


Table.7 Effect of bio control agent on Diameter of roots, Fresh weight of roots, Dry matter of roots

\begin{tabular}{|l|c|c|c|}
\hline Treatment & $\begin{array}{c}\text { Diameter of } \\
\text { roots }\end{array}$ & Fresh weight & Dry weight \\
\hline Control & 0.73 & 0.81 & 36.30 \\
\hline PSB & 1.63 & 1.35 & 46.63 \\
\hline Azotobactor & 1.33 & 1.26 & 42.23 \\
\hline Azospirillum & 1.37 & 1.27 & 43.50 \\
\hline Vermicompost & 1.50 & 1.30 & 43.33 \\
\hline
\end{tabular}
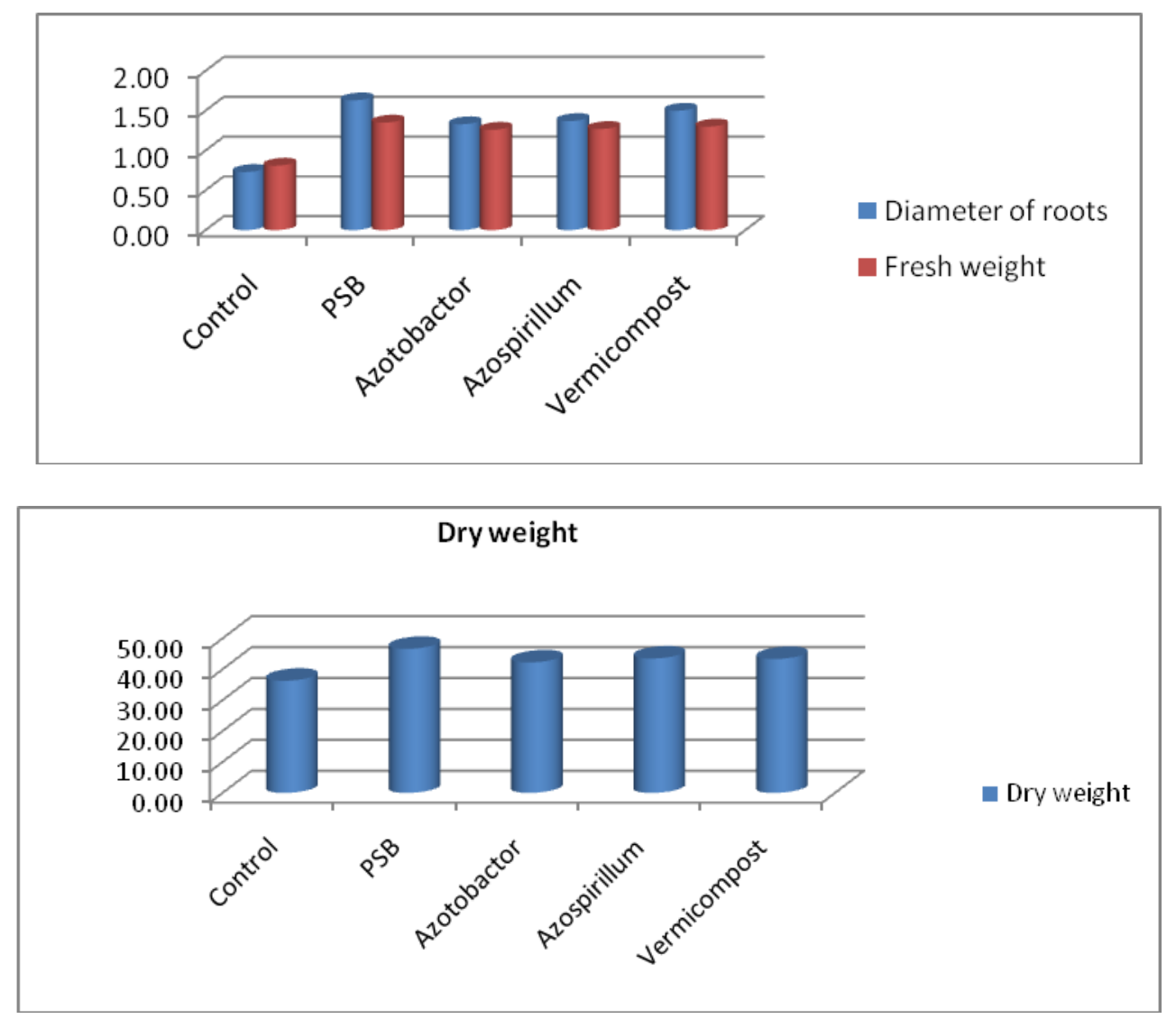

\section{Root characters}

\section{Number of roots per cutting}

The data presented in table 6 shows that the number of roots per cutting ranged from 25.27 to 31.67 . The maximum number of roots per cutting was observed under PSB @ $5 \%$ of rooting media (31.67).Whereas, minimum percentage $(56.67 \%)$ of success of cuttings was recorded under control.

\section{Length of roots $(\mathrm{cm})$}

The data presented in table 6 shows that the length of roots ranged from 20.96 to 26.39. The maximum length of roots was observed under PSB@ $0 \%$ of rooting media (26.39).Whereas, minimum length of roots (20.96) was recorded under control. The result is in same line with Nageswari et al., (1999). 


\section{Diameter of roots $(\mathrm{mm})$}

The data presented in table 7 shows that the diameter of roots ranged from to 0.73 to 1.63 The maximum diameter of roots was observed under PSB@ $5 \%$ of rooting media (1.63).Whereas, minimum diameter of roots (0.73) was recorded under control.

\section{Fresh weight of roots (g)}

The data presented in table 7 shows that the fresh weight of roots ranged from to 0.81 to 1.35. The maximum fresh weight of roots was observed under PSB@ 5\% of rooting media (1.35). Whereas, minimum fresh weight of roots $(0.81)$ was recorded under control. The result is in same line with Baqual et al., (2015).

\section{Dry matter of roots $(\%)$}

The data presented in table 7 shows that the dry matter of roots ranged from to $36.30 \%$ to $46.63 \%$. The maximum length of roots was observed under PSB@ 5\% of rooting media $(46.63 \%)$.Whereas, minimum dry matter roots $(36.30 \%)$ was recorded under control.

In conclusion, it was observed that use of various dose of biofertilizers resulted in better root and shoot development of pomegranate hardwood stem cutting in consideration with control.

Among the biofertilizers used first sprouting of cutting, sprouting of $50 \%$ of cuttings, highest success percent, root length, leaf count per longest shoot, fresh root weight, root diameter, dry matter content of root and root count per cutting was found to be maximum with application of PSB but survival percentage of cutting wah highest with application of Azotobactor and Azospirillum.

\section{References}

Hakim, A., Jagnnath, S., 2018Influence of Biofertilizer and Auxin on Growth and Rooting of Pomegranate (Punica granatum L.) Cuttings. Int.J.Curr.Microbiol.App.Sci (2018) 7(2): 1187-1193.

Joolka ,N.K., Singh ,R.R. and Shrma, M.K. 2004. Influnce of biofertilizers, GA3 and their combinations on the growth of pecan seedlings. Indian J. Hort., 61(3):226-228.

Nageswari, K., Pugalendhi, L. and Balkrishnamurthy, G. 1999. Studies into the effect of Biofertilizers (viz. Azospirillum and Phosphobacteria) on rooting of Cinnamon (Cinnanomum verum $\mathrm{P}$. resl) cuttings. Spice India., 12(11):9- 10.

Negi, J., Manhas, R.K., Chauhan, P.S., 2003 Carbon allocation in different components of some tree species of India: A new approach for carbon estimation. Current Science., 85(11): 1528-1531.

Rao, A.V. and Das, H.C. 1989. Growth of Fruit plants as influenced by nitrogen fixing bacteria in ber. Annuals of Arid Zone., 28(1-2):143-147.

Seeram, N.P., Adams, L.S., Henning, S.M., Niu, Y., Zhang, Y., Nair, M.G., Heber., D., 2005. In vitro antiproliferative, apoptotic and antioxidant activities of punicalagin, ellagic acid and a total pomegranate tannin extract are enhanced in combination with other polyphenols as found in pomegranate juice. J. Nutr. Biochem.16(6): 360-367.

Slankis, V. 1973. Hormonal relationship in mycorrhizal development. Academic press., 231-298.

Sonawane, R.B. and Konde, B.K. 1997. Response of grapevine to dual inoculation on VAM fungi and 
diazotrophs. J. Maharashtra Agric. Uni., 22(3):356-357.

Wahab, F. 1999. Rooting response of semi hardwood cuttings of guava (Psidium guajava $\mathrm{L}$.) to various concentrations of different auxins. M.Sc. (Agri.) Thesis. NWFP Agricultural University, Peshawar, Pakistan.

Wahab, F., Nabi, N. Ali and Shah M. 2001. Rooting Response of semi hardwood cuttings of guava (Psidium guajava L.) to various concentrations of different auxins. Journal of Biological sciences., 1 (4): 184-187.

Yadav, R. and Bhagel, B.S. 2002. Response of phalsa (Grewia- subinaequalis DC) cuttings to biofertilizers and rooting media. M.Sc. thesis in JNKVV, Jabalpur.

\section{How to cite this article:}

Jayashri Rathore, G.L. Sharma and Tapas Chaudhury. 2020. Effect of Biofertilizers and Vermicompost on Pomegranate (Punica granatum L.) Cutting. Int.J.Curr.Microbiol.App.Sci. 9(06): 1990-1999. doi: https://doi.org/10.20546/ijcmas.2020.906.245 